\title{
The population of Jernang rattan (Daemonorops draco) in Jebak Village, Batanghari District, Jambi Province, Indonesia
}

\author{
IIK SRI SULASMI ${ }^{1,2, \boldsymbol{\varphi}}$, NISYAWATI ${ }^{2,}$, YOHANES PURWANTO ${ }^{3}$, SITI FATIMAH $^{4}$ \\ ${ }^{1}$ State High School number 1 of Jambi. Jl. Urip Sumoharjo No 15, Telanai Pura, Jambi 36122. Indonesia. Tel. +62-741-63147, Fax. +62-741-61108, \\ "email: iik_08@yahoo.com \\ ${ }^{2}$ Conservation Biology Post Graduate School, Faculty of Mathematic and Natural Sciences, University of Indonesia, Depok 16436, West Java, Indonesia. \\ ${ }^{3}$ Research Center for Biology, Indonesian Institute of Sciences, Cibinong Bogor 16911, West Java, Indonesia. \\ ${ }^{4}$ State High School number 2 of Surakarta. Surakarta 57134, Central Java, Indonesia.
}

Manuscript received: 12 September 2012. Revision accepted: 18 October 2012.

\begin{abstract}
Sulasmi IS, Nisyawati, Purwanto Y, Fatimah S. 2012. The population of Jernang rattan (Daemonorops draco) in Jebak Village, Batanghari District, Jambi Province, Indonesia. Biodiversitas 13: 205-213. Research of Rattan Jernang (Daemonorops draco Willd.) population in Jebak Village, Batanghari District, Jambi had never been done before. Daemonorops draco is a plant that produces sap called dragon blood. Dragon blood is very useful for the the lives of people of Anak Dalam Tribe in Jambi. This research used purposive random sampling method. All of data were analyzed descriptively. The results showed that beside $D$. draco, there were other six species of rattan in Jebak forest. The population of $D$. draco in Jebak forest was only 8 clumps, consisting of 82 individuals. $D$. draco had the smallest population among all rattan species. Calamus javensis had the highest population, namely 11 clumps, consisting of 197 individuals. The research location had air temperature of $20.2^{\circ} \mathrm{C}-28.9^{\circ} \mathrm{C}$, relative humidity of $58 \%-68 \%$, and $\mathrm{pH}$ of $4.60-4.81$. In this location, there were 35 tree species (73 individuals) as supporting trees for $D$. draco to climb. The number of $D$. draco's supporting trees and $D$. draco was not balanced, causing the death of $D$. draco in Jebak forest. Vegetation analyses showed that there were 51 tree species with diameter $>10 \mathrm{~cm}$, consisting of 69 individuals. Pithecolobium saman had the highest importance value index (11) among all trees. There were also 33 tree species with diameter $\leq 10 \mathrm{~cm}$, consisting of 60 individuals. Pithecolobium saman also had the highest importance value index (20) in this group. Based on the interview, it is showed that the population of $D$. draco in Jebak forest declined because of illegal logging and forest encroachment.
\end{abstract}

Key words: Daemonorops draco, supporting trees, dragon blood, forest encroachment, illegal logging.

\section{INTRODUCTION}

The word Daemonorops is derived from Greek, daemo and rhops; daemo means devil, and rhops means shrub (Mogea 1991). In Indonesia, the genus Daemonorops consist of many species, namely 84 species (Beccari 1911), 113 species (Dransfield and Manokaran 1994), 115 species (Rustiami et al. 2004). According to Rustiami et al. (2004), of the 115 species of Daemonorops found in Indonesia, 12 species produce sap, namely $D$. acehensis, $D$. brachystachys, $D$. didymophylla, D. draco, D. dracuncula, D. dransfieldii. D. maculata, D. micracantha, D. rubra, D. sekundurensis, D. siberutensis, and D. uschdraweitiana. In Jambi, 10 species of Daemonorops are found, namely, $D$. brachystachys, D. didymophylla (Beccari 1911), D. dracuncula, D. dransfieldii, D. longipes (Dransfield 1984), D. palembanicus, D. singalamus, D. trichrous, D. draco (Dransfield 1992), and D. mattanensis (Soemarna 2009). According to Heyne (1987), only five species of rattan produce high quality of sap, namely $D$. didymophylla, $D$. draco, D. draconcellus, D. motleyi, and D. micracantha. Of the five species, $D$. draco produces the best jernang sap, which has many uses, such as coloring agent (Beccari 1911), ingredient of cosmetics (Dali and Soemarna 1985), and medicines for diarrhea (Winarni et al. 2004), for wound (Harata et al. 2005), and ingredient of tooth paste (Purwanto et al. 2009). Not only producing jernang sap, Daemonorops periacanthus, found only in Japan, also produces edible sweet fruit (Beccari 1911).

Indonesia is the largest jernang sap exporter in the world. The demand of Indonesian jernang sap from China is 400 ton-500 ton per year (Januminro 2000; Soemarna 2009), but Indonesia can export only 27 ton per year, worth US\$ 10,125,000 (Soemarna 2009). In addition to Sipintun and Lumbun Sigatal Villages, Jebak Village in Muara Tembesi Sub-District, Batanghari District, Jambi Province, also produces jernang sap as much as $300 \mathrm{~kg}$ per month (Jambi Forestry Office 2009).

Jebak Village has 15,830 ha of natural forest, but the forest is not utilized optimally because much of it has been damaged due to illegal logging and forest encroachment done by transmigrants coming mostly from Java and South Sumatra (Soemarna 2009; BKSDA Jambi 2010).

Forest degradation at an extent of 6,332 ha has caused the decline of population of supporting tree species on which the jernang rattan climb (BKSDA Jambi 2010), which in turn has caused the decline of jernang rattan population. As a result, the production of jernang sap has 
declined (Soemarna 2009). The degree of negative impact of illegal logging and forest encroachment on the population of jernang rattan population had not been documented. The objective of this study was to estimate the population of jernang rattan (Daemonorops draco Willd.) in Jebak Village. The results of this study can be used to complete the data of rattan population in Batanghari District, Jambi Province, Indonesia and as the basis for the development of this species in Jebak Village.

\section{MATERIALS AND METHODS}

\section{Study site}

The field work was done from January to February 2011 in forest area belonging to Anak Dalam Tribe (Suku Anak Dalam) in Jebak Village, Muara Tembesi SubDistrict, Batanghari District, Jambi Province. The location was selected based on the information that the Jebak forest is a habitat of jernang rattan (Daemonorops draco).

\section{Sampling method}

Sampling of data in the field was done using purposive random sampling method (Fachrul 2007; Simon 2007). Sampling plots were made only in the sites where $D$. draco was found. Within 25 hectares of research area, five $100 \mathrm{~m}$ $\mathrm{x} 100 \mathrm{~m}$ plots were made. Each plot was divided into 100 small plots measuring $10 \mathrm{~m} \times 10 \mathrm{~m}$ each. Within 100 small plots, the number of jernang rattan and all species of rattan were counted and categorized according to their growth stages following Dransfield (1984), INTAG (1989), Kalima (1991) and Siswanto (1991): (i) Seedling: length of stem < $3 \mathrm{~m}$, (ii) Juvenile: length of stem: 3-5 m, (iii) Semi mature: length of stem: 5-15 m, (iv), Mature: length of stem $>15 \mathrm{~m}$.

Within $10 \mathrm{~m} \times 10 \mathrm{~m}$ plots, the number of trees on which jernang rattan climbs was also counted. For vegetation analyses, two sizes of plots were made in one of the $100 \mathrm{~m}$ x $100 \mathrm{~m}$ plot, namely $10 \mathrm{~m} \times 10 \mathrm{~m}$ plots and $20 \mathrm{~m} \times 20 \mathrm{~m}$ plots, with a total area of 0.2 ha $(20 \mathrm{~m} \times 100 \mathrm{~m})$. Trees with a diameter $>10 \mathrm{~cm}$ were counted in $20 \mathrm{~m}$ x $20 \mathrm{~m}$ plots, while trees with a diameter $\leq 10 \mathrm{~cm}$ were counted in $10 \mathrm{~m} \mathrm{x}$ $10 \mathrm{~m}$ plots. The data of trees were used as supporting data. The names of species and number of individual trees were recorded to determine the frequency and density of each species. Identification of trees was not done because the local and scientific names of trees had been given.

\section{Data analyses}

Importance value index was counted for each species using formula cited in Rugayah et al. (2004) and Simon (2007). From the importance value, dominance index was determined using the formula cited in Simon (2007), namely:

\section{$\mathrm{ID}=\Sigma \_$ni $/ \mathrm{N} \_2$}

$\mathrm{ID}=$ dominance index for each tree species,

$\mathrm{ni}=$ importance value of each tree species,

$\mathrm{N}=$ total importance value indexes.

Criteria for Simpson dominance indexes were $0<\mathrm{C}<$ $0.5=$ low dominance; $0.5<\mathrm{C}<0.75=$ medium dominance; $0.75<\mathrm{C}<1=$ high dominance

\section{RESULTS AND DISCUSSION}

\section{Population of jernang rattan and others}

According to Rustiami (2004), Daemonorops draco Willd. is also known as Calamus draco Willd. and Daemonorops propinqua Becc. The species has many local names in Indonesia, namely rotan jernang (Malay), limbayung (West Sumatra), huar (Dayak-Busang), seronang (Dayak-Penihing), uhan (Dayak-Kayan), getih badak (Sundanese), getih warak (Javanese). The jernang rattan is distributed in two islands, namely Sumatra (Jambi, Bengkulu, Riau Archipelago Provinces), and Kalimantan. The species grows in clumps in valleys and is commonly found in flood plain near rivers.

In Jambi, there were 10 species of Daemonorops, namely D. brachystachys, D. didymophylla (Beccari 1911), D. dracuncula, D. dransfieldii, D. longipes (Dransfield 1984), D. palembanicus, D. singalamus, D. trichrous, D. draco (Dransfield 1992), and D. mattanensis (Soemarna 2009). Currently only three species can be found in Jambi, namely $D$. didymophylla, D. draco, and D. mattanensis. The three species can be found in the Districts of Batanghari, Sarolangun, Tebo, and Tanjung Jabung (Soemarna 2009). Based on the information from the jernang sap seekers in Jebak Village, Malay people in Jambi know two jernang sap producing rattans, namely rotan jernang (D. draco) and rotan kelukup (Daemonorops didymophylla), while the people of Anak Dalam Tribe in Jebak Village call the two species rotan jernang (D. draco) and rotan mengkarung/kelemunting (D. didymophylla). The jernang rattan has longer panicles and high density of flower, darker fruit and more abundant, higher quality and more expensive sap than the kelemunting. The people of Anak Dalam Tribe in Jebak Village can easily distinguish jernang rattan from other rattans from the stems, leaves, fruits, and spines. Jernang rattan has diameter between $1 \mathrm{~cm}$ to $3 \mathrm{~cm}$, reddish green leaves, shinny black fruit, the skin being scaly when extracted. It has stem internodes between $15 \mathrm{~cm}$ to $40 \mathrm{~cm}$ long, and the whole stem is covered by black spines which do not shed until old age. The number of stems in a clump is between 5 to 20 individuals, with the height between $8 \mathrm{~m}$ to $15 \mathrm{~m}$.

According to jernang sap seekers, the cane of $D$. draco can be used to make household equipments. But the quality of cane is not good, so the people of Anak Dalam Tribe only infrequently use it. Figure 1. shows the differences between jernang rattan and batang rattan, young leaves of female jernang rattan, jernang rattan fruit. Jernang rattan can be easily distinguished from other rattan from its stem, leaves, and fruit. Jernang has many spines, light green or reddish green leaves and black fruit.

According to Rustiami (2004) and Winarni et al. (2004), the characteristics distinguishing $D$. draco from other Daemonorops are the followings: Its height is $8 \mathrm{~m}-$ $15 \mathrm{~m}$, the length of internodes $20 \mathrm{~cm}$; the breadth of sheath $30 \mathrm{~mm}$; the length of leaf $3 \mathrm{~m}$, the length of cirrus $100 \mathrm{~cm}$, petiole $10 \mathrm{~cm}$; diameter of stem $10 \mathrm{~mm}-30 \mathrm{~mm}$. The leaves have sheath circling the stem. The fruit skin is scaly like salacca's fruit. The spines are arranged in a structure called the knee (Figure 1). 


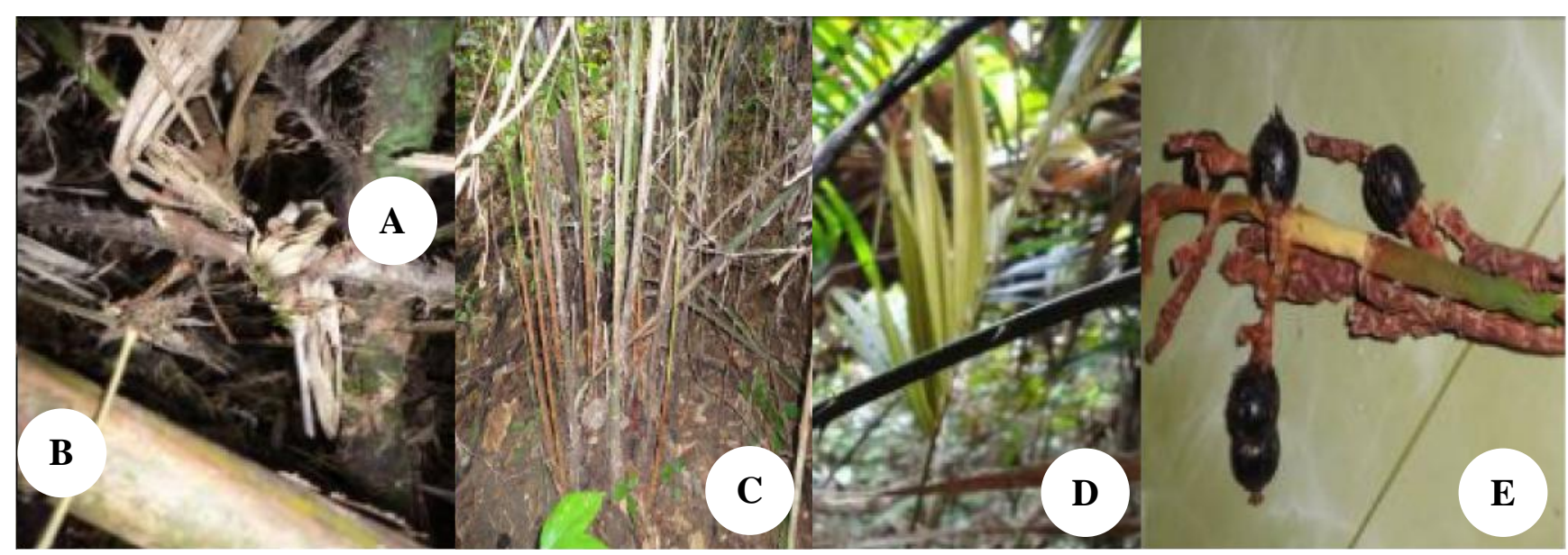

Figure 1.A. Stem of jernang rattan, B. Stem of batang rattan (Calamus), C. Seedlings, D. Young leaves of female jernang rattan, E. Jernang rattan fruit.

The differences between female and male jernang rattan can be seen from the bracts, young leaves, flower, internodes, and number of individuals in a clump (Table 1).

Daemonorops draco is a dioecious plant. Female flowers and male flowers are produced in different rattan clumps. D. draco starts producing fruit at the age of two years, but it starts producing jernang sap when it is 5 years old (Winarni et al. 2004). A clump of $D$. draco generally consists of 5-20 individuals (BKSDA Jambi 2010).

Based on the report from the Forestry Office of Jambi Province in 2009, the population of jernang rattan in Jambi is relatively small, as shown in detail in Table 2 . Table 2 shows that the smallest population in nature is found in Batanghari District, which is 40 clumps, because since 1990, illegal logging and forest encroachment in Jebak Village, Batanghari District has been the largest among all districts (BKSDA Jambi 2010). Therefore, in 2008 two people from Anak Dalam Tribe started planting 40 clumps of rattan under the guidance of Forestry Office of Batanghari District (Jambi Forest Office 2009). However, only 25 clumps survive, because the other 15 clumps were consumed by pigs. According to jernang rattan farmers, since November 2011, the planted jernang rattans have produced sap as much as $30 \mathrm{~kg}$.

The results of our study showed that the population of jernang rattan in Anak Dalam Tribe forest area in Jebak Village has declined. Our study only found 8 clumps of jernang rattan consisting of 82 individuals (stems). Table 2 shows that the population in nature has declined from 40 clumps/ha in 2009 to 8 clumps in 25 ha in 2011. The decline of rattan population is caused by illegal logging and forest encroachment done by transmigrants and other outside communities. According to Anak Dalam Tribe, the damage due to illegal logging and forest encroachment in 2011 was $60 \%$ from the total of 15.830 ha of forest belonging to the tribe. Transporting timber in the forest is done using skid road made of timber. Many jernang rattans die because there are not enough supporting trees to climb.
Table 1. The differences between female jernang rattan and male jernang rattan

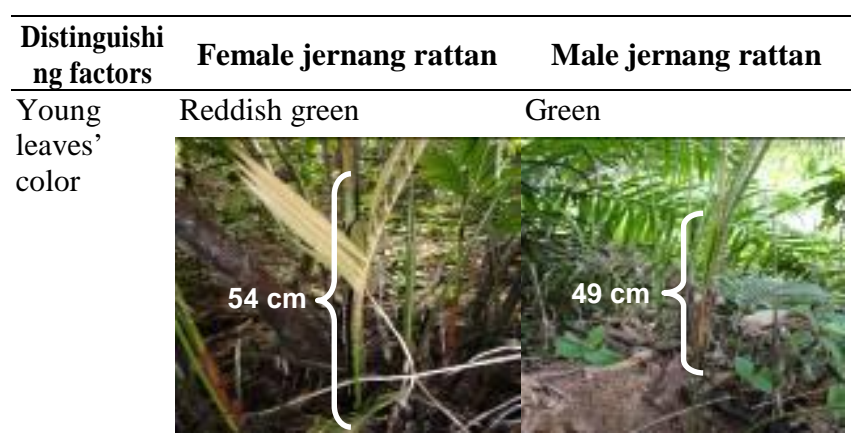

Internodes

$15 \mathrm{~cm}-20 \mathrm{~cm}$

$35 \mathrm{~cm}-40 \mathrm{~cm}$

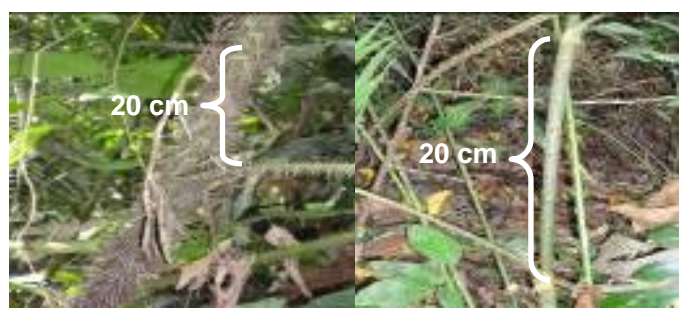

Bracts

Large Small

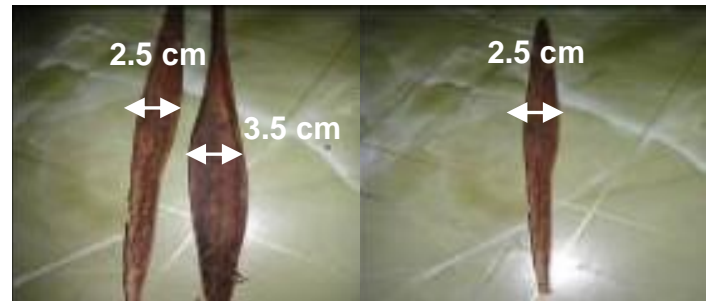

Number of

5-20 individuals

3-5 individuals

individuals in a clump

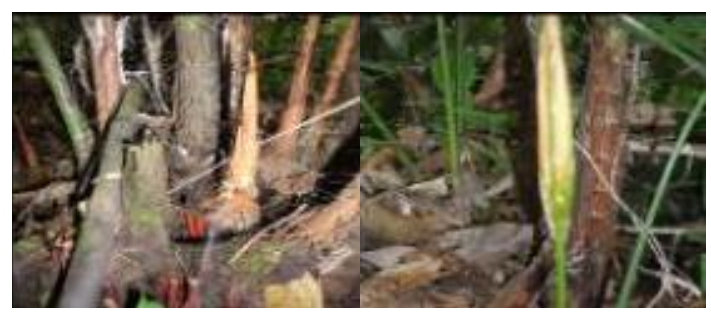


Table 2. The population of naturally growing jernang rattan and planted jernang rattan in Jambi Province based on the Forestry Ofiice report and on research data in 2011.

\begin{tabular}{llll}
\hline \multicolumn{1}{c}{ District } & $\begin{array}{c}\text { Population } \\
\text { in nature } \\
\text { per hectare }\end{array}$ & \multicolumn{1}{c}{ Plantation } & $\begin{array}{c}\text { Research } \\
\text { data }\end{array}$ \\
\hline Batanghari & 40 clumps & In 2008, plantation was started in jebak Village, consisting of 40 clumps. & 8 clumps \\
Sarolangun & 53 clumps & $\begin{array}{l}\text { In 2006, plantation was started in Sipintun and Lumban Sigatal villages, consisting } \\
\text { of 500 clumps. Rattans were planted in rubber plantation at the extent of 10 ha. }\end{array}$ & 8 clumps \\
Tebo & 71 clumps & $\begin{array}{l}\text { Plantation has not been done. } \\
\text { Plantation has not been done. }\end{array}$ & 8 clumps \\
Tanjung Jabung & 69 clumps & clumps \\
\hline
\end{tabular}

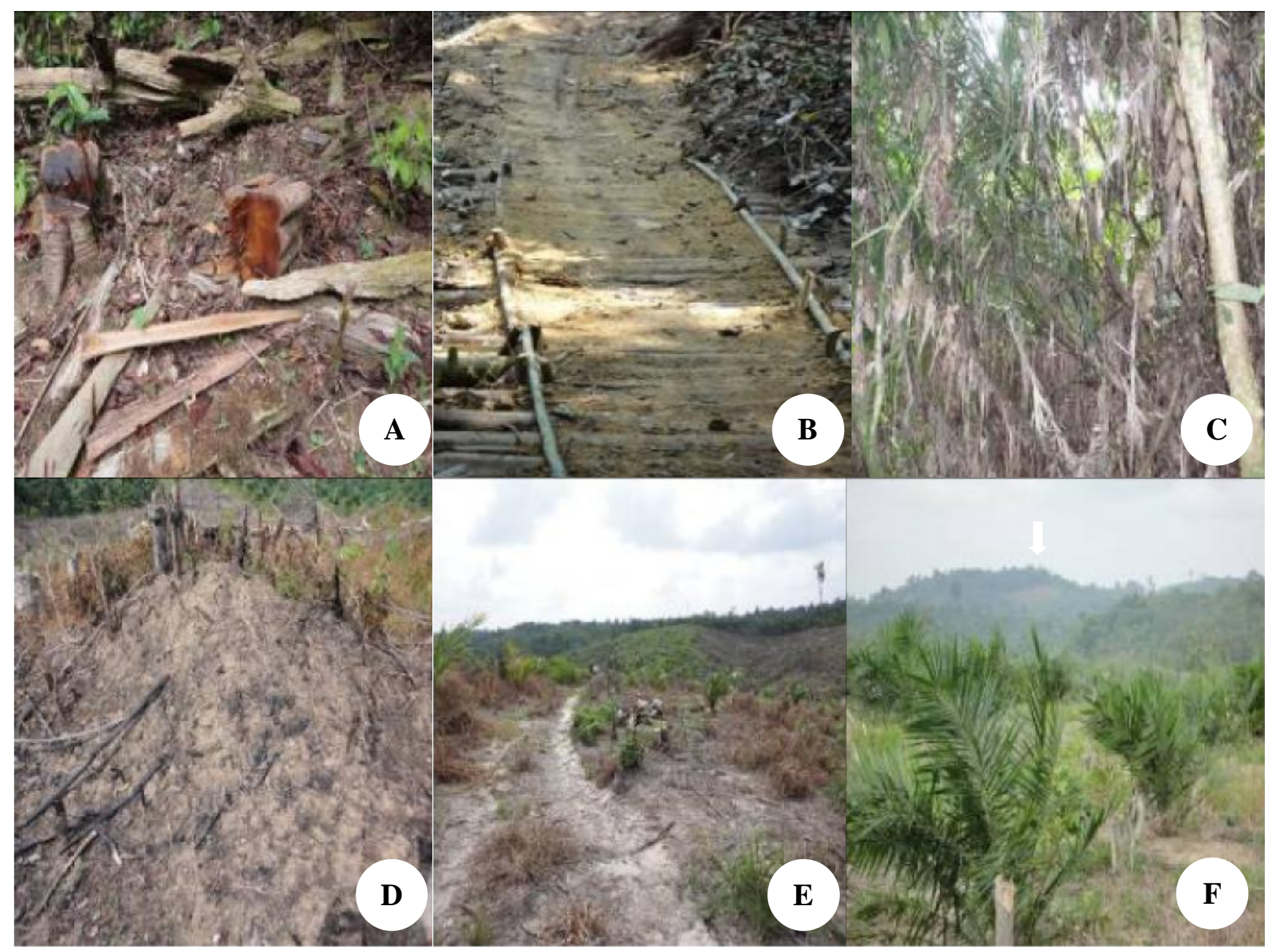

Figure 2. Pictures of forest encroachment in Jebak Village: $\mathrm{A}=$ encroachment; $\mathrm{B}=$ skid road to facilitate timber transportation, $\mathrm{C}=$ jernang rattan died because there was no supporting tree, $\mathrm{D}=$ forest fire; $\mathrm{E}-\mathrm{G}=$ conversion of forest into oil palm plantation; $\mathrm{F}$. indicates an area inside Anak Dalam Tribe forest being encroached.

After the death of jernang rattan, people burn the forest to clear the land for oil palm plantation, 2-3 months later (Figure 2). The information was in agreement with the data from BKSDA Jambi (2010) stating that the forest damage in 2009 was $40 \%$ of 15.830 hectare, resulting in the decline of trees on which the jernang rattan climb. The damage of forest can be seen from the conversion of forest into oil palm plantation.

Since 1990, the encroachment of forest has grown out of control because of lack of supervision from the government and because of unclearness of the boundary between the forest area and the villages around the area. The encroachment is done not only by transmigrants, but also by several oil palm plantation companies in the surrounding areas. (The companies are PT. Asiatic Persada in the west, PT. Tunjuk Langit Sejahtera and Batanghari Sawit Persada in the north, and PT. Nan Riang in the east of the forest area).

According to the people of Anak Dalam Tribe, before 1990 , they could easily get the sap because the population density of jernang rattan was still high. Within less than 6 hours, they could collect jernang rattan fruit as much as 60 
$\mathrm{kg}-180 \mathrm{~kg}$ per family. That amount was collected from 3-6 clumps of jernang rattan. After 1990, they could collect jernang fruit only $3 \mathrm{~kg}-20 \mathrm{~kg}$ per day, taken from 1 clump of jernang rattan. In 2010, the population of jernang rattan in Jebak Village was $15-30$ clumps, but in 2011 , only 8 clumps left, consisting of 82 individuals. The composition of growth stages of the 83 individuals are given in Figure 3. Figure 3 shows that the number of seedlings was much higher than the mature individuals, so the production of jernang sap was low. But, the abundant seedlings also ensure the sustainability of jernang rattan in the future if illegal logging and forest encroachment is stopped, so the number of supporting trees on which rattan climb is sufficient.

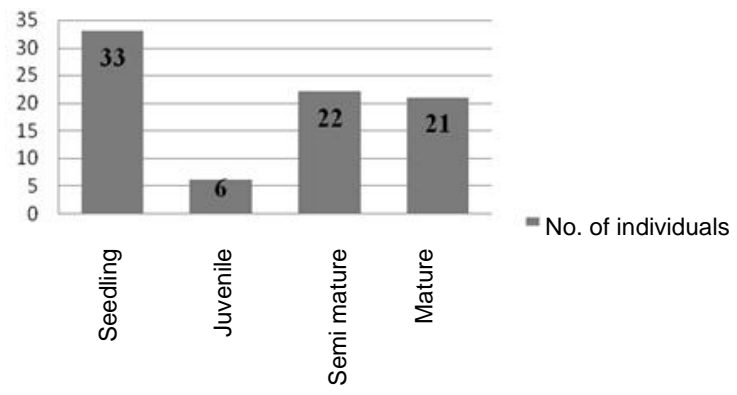

Figure 3. The number of jernang rattan individuals at different growth stages in Jebak Village in 2011.

The complete data of the number of individuals of jernang rattan is given in Table 3 . In plot 1 , a clump of young female rattan (5 individuals) was found. One clump died in plot 4 because there was no supporting tree to climb. In plot 11 , a clump of female rattan was found (5 seedlings and 5 semi mature individuals). Two clumps died in plots 13 and 16. In plot 21 a clump of semi mature male jernang rattan was found ( 3 individual), and clump died in plot 24.In plot 31 a clump of female jernang rattan was found (3 individuals of seedling, 3 individuals of juvenile, and 7 individuals of semi mature rattan). In plot 35 a clump of semi mature male jernang rattan was found (5 individuals), and a clump died in plot 38 . In plot 41 a clump of female rattan was found ( 5 individuals of seedlings, 3 individuals of juvenile, 2 individuals of semi mature, and 10 individual of mature rattan). In plot 43 a clump of female jernang rattan was found (10 individuals of seedlings, 4 individuals of semi mature and 7 individuals of mature rattan). In plot 45 a clump of rattan died. In plot 47 a clump of female jernang rattan was found (5 individuals of seedlings, and 4 individuals of mature rattan). In plot 50 a clump of rattan died. Table 3 shows that jernang rattan population was distributed widely in each plot.

Overall, there were 2 clumps of male jernang rattan $(8$ individuals), 6 clumps of female jernang rattan (74 individuals) (Figure 4), and 7 clumps of jernang rattan died. Because the number of female and male rattans was not equal and their locations were separated widely, natural reproduction of jernang rattan did not occur easily. To overcome this constraint, artificial pollination has been conducted.
Table 3. Number of individuals of jernang rattan in Jebak Village

\begin{tabular}{|c|c|c|c|c|}
\hline \multirow{2}{*}{$\begin{array}{c}\text { Plot } \\
\text { nos }\end{array}$} & \multicolumn{4}{|c|}{ Jernang rattan population (ind.) } \\
\hline & Seedlings & Juvenile & $\begin{array}{c}\text { Semi } \\
\text { mature }\end{array}$ & Mature \\
\hline 1 & 5 & - & - & - \\
\hline 2 & - & - & - & - \\
\hline 3 & - & - & - & - \\
\hline $4 \dagger$ & - & - & - & - \\
\hline 5 & - & - & - & - \\
\hline 6 & - & - & - & - \\
\hline 7 & - & - & - & - \\
\hline 8 & - & - & - & - \\
\hline 9 & - & - & - & - \\
\hline 10 & - & - & - & - \\
\hline 11 & 5 & - & 5 & - \\
\hline 12 & - & - & - & - \\
\hline $13 \dagger$ & - & - & - & - \\
\hline 14 & - & - & - & - \\
\hline 15 & - & - & - & - \\
\hline $16 \dagger$ & - & - & - & - \\
\hline 17 & - & - & - & - \\
\hline 18 & - & - & - & - \\
\hline 19 & - & - & - & - \\
\hline 20 & - & - & - & - \\
\hline $210^{\pi}$ & - & - & 3 & - \\
\hline 22 & - & - & - & - \\
\hline 23 & - & - & - & - \\
\hline $24 \dagger$ & - & - & - & - \\
\hline 25 & - & - & - & - \\
\hline 26 & - & - & - & - \\
\hline 27 & - & - & - & - \\
\hline 28 & - & - & - & - \\
\hline 29 & - & - & - & - \\
\hline 30 & - & - & - & - \\
\hline 31 & 3 & 3 & 7 & - \\
\hline 32 & - & - & - & - \\
\hline 33 & - & - & - & - \\
\hline 34 & - & - & - & - \\
\hline $350^{\pi}$ & - & - & 5 & - \\
\hline 36 & - & - & - & - \\
\hline 37 & - & - & - & - \\
\hline $38 \dagger$ & - & - & - & - \\
\hline 39 & - & - & - & - \\
\hline 40 & - & - & - & - \\
\hline 41 & 5 & 3 & 2 & 10 \\
\hline 42 & - & - & - & - \\
\hline 43 & 10 & - & $4(\dagger)$ & 7 \\
\hline 44 & - & - & - & - \\
\hline $45 \dagger$ & - & - & - & - \\
\hline 46 & - & - & - & - \\
\hline 47 & 5 & - & - & 4 \\
\hline 48 & - & - & - & - \\
\hline 49 & - & - & - & - \\
\hline $50 \dagger$ & - & - & - & - \\
\hline Total & 33 & 6 & 22 & 21 \\
\hline
\end{tabular}

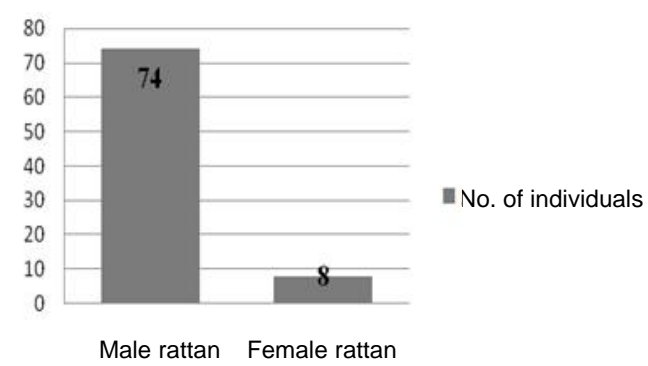

Figure 4. Comparison of number of female and male individuals of jernang rattan in 2011 
The comparison of population between jernang rattan and other rattans in Jebak Village is presented in Table 4. The detailed information of rattan population in Jebak Village is given in Table 5.

Table 4. Population of rattan in Jebak Village.

\begin{tabular}{llcc}
\hline \multicolumn{1}{c}{ Local names } & \multicolumn{1}{c}{ Scientific names } & $\begin{array}{c}\Sigma \\
\text { clumps }\end{array}$ & $\begin{array}{c}\Sigma \\
\text { Ind }\end{array}$ \\
\cline { 2 - 3 } Rotan lilin & Calamus javensis Bl. & 11 & 197 \\
Rotan semambu & Calamus scipionum Lour. & 9 & 178 \\
Sego air & Calamus axillaris Becc. & 9 & 103 \\
Rotan getah & Daemonorops melanochaetes Bl. & 10 & 102 \\
Rotan dahan & Calamus flagellaris Burr. & 8 & 95 \\
Rotan manau & Calamus manan Miq. & 8 & 93 \\
Rotan jernang & Daemonorops draco Willd. & 8 & 82 \\
\hline
\end{tabular}

Table 5. Population of rattan in Jebak Village in 2011

\begin{tabular}{|c|c|c|c|c|c|c|c|}
\hline Number of individuals & 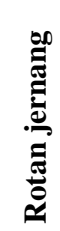 & 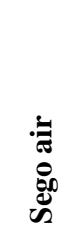 & 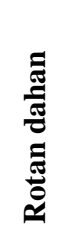 & 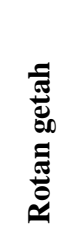 & 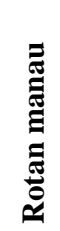 & $\begin{array}{l}\stackrel{\Xi}{\Xi} \\
\stackrel{\Xi}{\Xi} \\
\stackrel{\Xi}{*}\end{array}$ & 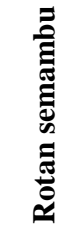 \\
\hline Seedlings & 33 & 21 & 20 & 23 & 14 & 24 & 24 \\
\hline Juvenile & 6 & 20 & 30 & 24 & 18 & 41 & 39 \\
\hline Semi mature & 22 & 35 & 16 & 23 & 35 & 63 & 44 \\
\hline Mature & 21 & 27 & 29 & 32 & 26 & 69 & 71 \\
\hline Total & 82 & 103 & 95 & 102 & 93 & 197 & 178 \\
\hline
\end{tabular}

It can be seen in Table 4 that jernang rattan had the smallest number of individuals. This may be due to illegal logging and forest encroachment which result in the shrink of jernang rattan habitat. Meanwhile, the populations of rotan lilin (Calamus javensis) and rotan semambu (Calamus scipionum) were relatively large because, according to the community, these two species have low economic value. The canes from these species have low quality because they are easily broken. Of the 7 species above, beside jernang rattan, rotan manau (Calamus manan) also has high economic value. The cane of rotan manau has the highest quality among all the species and it is flexible, so it can be easily made into desirable forms (Soemarna 2009).

\section{Habitat of jernang rattan in Jebak Village}

The results showed that in 2011 the forest in Jebak Village had been damaged by illegal logging and encroachment, so the vegetation was sparse. The relatively open vegetation caused the relatively wide range of air temperature, $20.2^{\circ} \mathrm{C}-28.9^{\circ} \mathrm{C}$, and low relative humidity, $58 \%-68 \%$ (Table 6).

The sparse vegetation results in low transpiration, so the water vapor is little, and consequently the humidity is low. Bernatzky (1978) said that water vapor in the air from evapotranspiration affects air humidity. Table 7 shows that in 2005-2009 the range of air temperature was not wide and the relative humidity was high, $80 \%-87 \%$. These phenomena indicated that the vegetation in that period was dense, so the water vapor from transpiration was large; therefore, the humidity was high.

Table 6. Air temperature, relative humidity, soil $\mathrm{pH}$ in Jebak Village, during research period in 2011.

\begin{tabular}{llccc}
\hline & \multicolumn{4}{c}{ Parameters measured } \\
Day/date & Plot no. & $\begin{array}{c}\text { Temp. } \\
\text { Relative } \\
\text { humidity }\end{array}$ & $\begin{array}{c}\text { Soil } \\
\text { (\%) }\end{array}$ & pH \\
\hline Monday/3-1-2011 & 1 & 23.1 & 65 & 4.71 \\
Wed./5-1-2011 & 2 & 24.2 & 64 & 4.71 \\
Thurs./6-1-2011 & 5 & 25.1 & 63 & 4.70 \\
Wed./12-1-2011 & 6 & 25.1 & 63 & 4.71 \\
Thurs./13-1-2011 & 10 & 26.0 & 60 & 4.74 \\
Sat/15-1-2011 & 11 & 25.9 & 60 & 4.75 \\
Tuesday/18-1-2011 & 15 & 26.8 & 59 & 4.70 \\
Thurs./20-1-2011 & 20 & 27.0 & 59 & 4.61 \\
Monday/24-1-2011 & 21 & 27.0 & 59 & 4.61 \\
Tuesday/25-1-2011 & 25 & 27.5 & 59 & 4.64 \\
Thurs/27-1-2011 & 30 & 28.6 & 58 & 4.61 \\
Wed./2-2-2011 & 31 & 28.6 & 58 & 4.60 \\
Sat./5-2-2011 & 33 & 28.5 & 58 & 4.62 \\
Tuesday/8-2-2011 & 35 & 28.9 & 58 & 4.62 \\
Wed/9-2-2011 & 37 & 28.9 & 58 & 4.62 \\
Thurs/10-2-2011 & 40 & 23.0 & 66 & 4.68 \\
Sat./12-2-2011 & 41 & 22.9 & 66 & 4.68 \\
Monday/14-2-2011 & 43 & 22.9 & 66 & 4.77 \\
Thurs./17-2-2011 & 47 & 20.2 & 68 & 4.81 \\
Monday/21-2-2011 & 50 & 21 & 68 & 4.81 \\
\hline & & & &
\end{tabular}

The soil in Jebak village is acidic $(\mathrm{pH} \mathrm{4,60-4,81)} \mathrm{and}$ belongs to yellow red podzolic soil type (Soemarna 2009). The village has an altitude of $20 \mathrm{~m}$ above sea level with annual rainfall of 1500-2296 mm (BPS 2010).

Table 7. The average temperature, relative humidity and rainfall in Jebak Village in 2005-2009 (BPS 2006-2010)

\begin{tabular}{lccc}
\hline Month & $\begin{array}{c}\text { Air } \\
\text { temperature } \\
\left(\mathbf{(}^{\mathbf{C}}\right)\end{array}$ & $\begin{array}{c}\text { Relative humidity } \\
(\mathbf{\%})\end{array}$ & $\begin{array}{c}\text { Rainfall } \\
(\mathbf{m m})\end{array}$ \\
\hline January & 25.9 & 86 & 126 \\
February & 25.4 & 87 & 243 \\
March & 25.9 & 85 & 207 \\
April & 26.4 & 84 & 167 \\
May & 27.5 & 80 & 137 \\
June & 27.3 & 81 & 129 \\
July & 26.9 & 83 & 70 \\
August & 26.8 & 82 & 123 \\
September & 27.4 & 81 & 139 \\
October & 26.9 & 83 & 157 \\
November & 26.6 & 84 & 245 \\
December & 26.5 & 85 & 254 \\
\hline
\end{tabular}

Jernang rattan is an endemic species of Sumatra (Soemarna 2009). In Jebak Village jernang rattan is found mostly in dry flood plain. According to Soemarna (2009), jernang rattan grows in acidic yellow red podzolic soil, with $\mathrm{pH}$ of 4-6, in lowland, with annual rainfall of 1000$2300 \mathrm{~mm}$, air temperature of $24-32^{\circ} \mathrm{C}$, and relative humidity of $60-85 \%$. Plantation of jernang rattan will produce the best result if it is done in its natural habitat. The forest area in Jebak village is suitable for the development of jernang rattan. 

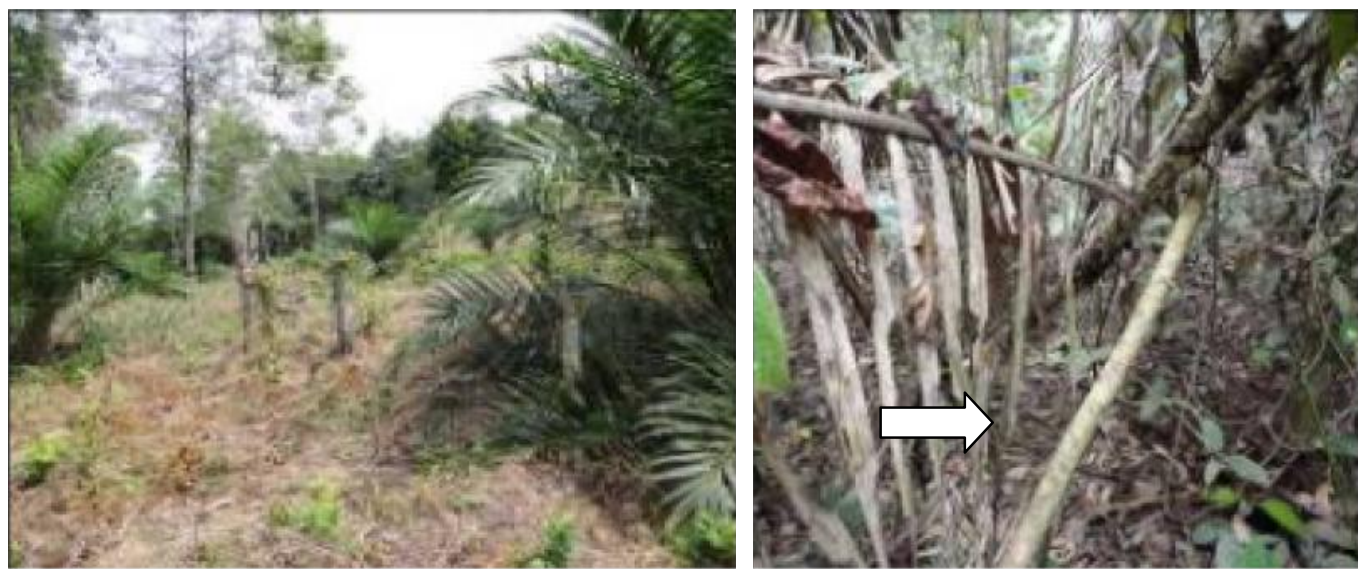

Figure 5. Forest encroachment results in the death of jernang rattan because there is no supporting tree.

\section{Species diversity of jernang rattan supporting trees}

Jernang rattan is a liana. Its life depends on the supporting tree on which it climbs. If the population of supporting trees declines due to forest degradation, the population jernang rattan will decline too (Figure 5.).

In Jebak Village, jernang rattan is usually found climbing 7 species of trees, namely keranji, berangan, duku, durian, meranti bunga, kayu tahi, and sekentut. These 7 species were frequently found in sampling plots. However, their population has declined due to forest degradation. The comparison of the number of individuals of jernang rattan and the supporting trees is presented in Table 8. Study on jernang rattan supporting trees had not been conducted.

It can be seen from Table 8 that all tree species can become jernang rattan supporting trees. According to Mogea (2002), Jasni et al. (2007) and Soemarna (2009), all tree species in forest can become supporting trees for jernang rattan to climb. However, since the number of supporting trees is not balanced with the number of jernang rattan individuals (82), the possibility of jernang rattan to die is high because of the lack of supporting trees. Table 8 also shows that some tree species were clustered in one location, while other species were distributed in several locations. The results of this study showed that to grow optimally, each individual jernang rattan needed 4 supporting trees. This result is in agreement with the statement of Soemarna (2009) that each jernang rattan needs 4 supporting trees. If there is no supporting tree or the number of supporting trees is small, then jernang rattan will not survive.
Table 8. Jernang rattan supporting trees in jebak Village.

\begin{tabular}{|c|c|c|c|}
\hline Local names & Scientific names & No. of ind. & Plot nos \\
\hline Keranji & Dialium platysepalum Backer & 4 & $1,11,31,47$ \\
\hline Berangan & Quercus elmeri Merr. & 4 & $21,31,41$ \\
\hline Kelat & Eugenia sp. Verdc. & 4 & 11,41 \\
\hline Medang api & Adinandra dumosa Jack & 4 & 21,41 \\
\hline Duku & Lansium domesticum Corr. & 3 & $31,41,47$ \\
\hline Durian & Durio zibethinus Murr. & 3 & $11,31,43$ \\
\hline Meranti bunga & Shorea teysmanniana $\mathrm{Bl}$. & 3 & $31,41,43$ \\
\hline Kayu tahi & Celtis wightii Planch. & 3 & $1,31,47$ \\
\hline Sekentut & Saprosma arboreum Blume & 3 & $21,31,43$ \\
\hline Berangan babi & Castanopsis inermis Lindl & 3 & 31,43 \\
\hline Siluk & Gironniera subaequalis Planch. & 3 & 31,41 \\
\hline Tempinis & Sloetia elongata Kds. & 2 & 21,43 \\
\hline Kempas & Koompassia malaccensis Maing. & 2 & 31,35 \\
\hline Kayu arang & Diospyros pilosanthera Blanco & 2 & 35,41 \\
\hline Jelutung & Dyera costulata Miq & 2 & 11,43 \\
\hline Kepayang & Pangium edule Reinw. & 2 & 21,35 \\
\hline Trembesi & Pithecolobium saman Jacq. & 2 & 1,47 \\
\hline Kedondong & Spondias cytherea Forst & 2 & 35,47 \\
\hline Jengkol & Pithecellobium lobatum Benth & 2 & 31,35 \\
\hline Petai & Parkia speciosa Hassk & 2 & 31,47 \\
\hline Ambacang & Mangifera foetida Lour. & 2 & 1 \\
\hline Medang & Litsea sp. Lam. & 2 & 35 \\
\hline Cempedak & Artocarpus champeden Lour. & 2 & 47 \\
\hline Simpur rawang & Dillenia indica L. & 1 & 47 \\
\hline Medang serai & Cinnamomum parthenoxylon Jack & 1 & 11 \\
\hline Rambutan & Nephelium lappaceum L. & 1 & 1 \\
\hline Mahang & Macaranga hypoleuca Rechb. & 1 & 1 \\
\hline Brumbung & Adina minutiflora Val. & 1 & 31 \\
\hline Kabau & Archidendron bulbalium Jack & 1 & 21 \\
\hline Tempunek & Artocarpus rigida Blume & 1 & 11 \\
\hline Kayu batu & Rhodamnia sp. & 1 & 35 \\
\hline Kelat jambu & Eugenia densiflora Blume & 1 & 31 \\
\hline Kayu terap & Artocarpus elastic Willd. & 1 & 35 \\
\hline Tampui & Baccaurea crassifolia J. J. Sm. & 1 & 35 \\
\hline Merpayang & Scaphium macropodum & 1 & 47 \\
\hline \multirow[t]{2}{*}{ Rotan jernang } & Daemonorops draco Willd. (82 in & & \\
\hline & Total & 73 & \\
\hline
\end{tabular}

\section{Diversity of tree species}

The trees found in the study area were divided into two groups, those with stem diameter $>10 \mathrm{~cm}$ (Table 9) and 
those with diameter $\leq 10 \mathrm{~cm}$ (Table 10). All tree species had been identified by Forestry Office of Batanghari District, so tree identification was not done in this study.

Table 9 shows that the species of trees found abundantly in the study site were, among others, trembesi. pinang, and sungkai. The abundance of those tree species indicates that those species have high adaptation capability, so they grow fast in Jebak forest area. Ecologically, those species have positive role for jernang rattan population because those trees can become supporting trees for jernang rattan.

It can be seen from Table 10 that tree species with stem diameter $\leq 10 \mathrm{~cm}$ which had the highest importance value index (20) was trembesi. (rain tree) That species was found in highest number of individuals among all trees in the ecosystem. Keranji and sekentut had the same IVI, which was 10. The relatively large differences in IVI are caused by forest degradation which lead to the decline of plant population, which in turn affects dominance value in ecosystem. According to Irawan (2002, 2003), the low IVI of several species in Jebak forest was due to the low population caused by illegal logging. While Peluso (1992) stated that the decline of population of a species is due to over exploitation of that species.

In general, the dominance of trembesi (rain tree) among all tree species population was categorized as low. The dominance indexes of trembesi for tree with diameter > $10 \mathrm{~cm}$, and $\leq 10 \mathrm{~cm}$ were low, namely 0.00123 and $\leq 10 \mathrm{~cm}$ were 0.00018 , respectively. This is in accordance with the criteria of Simpson Dominance Index, namely $0<\mathrm{C} \leq 0.5=$ low dominance; $0.5<$ $\mathrm{C} \leq 0.75=$ medium dominance; $0.75<\mathrm{C} \leq$ $1.00=$ high dominance.

\section{CONCLUSION AND RECOMENDATION}

The population of jernang rattan in Jebak forest in 2011 was 8 clumps, consisting of 82 individuals. The life or jernang rattan depends highly on the supporting trees on which jernang rattan climbs. All trees can become supporting trees for jernang rattan. There were 35 species of supporting trees, consisting of 73 individuals in Jebak forest. The tree species in Jebak Village on which jernang rattan usually climbed were berangan (Quercus elmeri), duku (Lansium domesticum), durian (Durio zibethinus), kelat (Eugenia sp.), kempas (Koompassia malaccensis), keranji (Dialium platysepalum), mahang (Macaranga hypoleuca), and
Table 9. Importance value index (IVI), number of individuals (n), density (n/ ha), and dominance index (DI) of trees with stem diameter $>10 \mathrm{~cm}$

\begin{tabular}{|c|c|c|c|c|c|}
\hline Local names & Scientific names & IVI & $\mathbf{n}$ & n/ha & DI \\
\hline Trembesi & Pithecolobium saman Jacq. & 11 & 2 & 10 & 0.00123 \\
\hline Keranji & Dialium platysepalum Backer & 9 & 2 & 10 & 0.0009 \\
\hline Punak & Tetramerista glabra Miq. & 8.8 & 2 & 10 & 0.00086 \\
\hline Jelutung & Dyera costulata Miq. & 8.8 & 2 & 10 & 0.00086 \\
\hline Mahang & Macaranga hypoleuca Rechb. & 8.5 & 2 & 10 & 0.00081 \\
\hline Manggis & Garcinia mangostana $\mathrm{L}$. & 8.4 & 2 & 10 & 0.00079 \\
\hline Kayu batu & Rhodamnia sp. & 8.1 & 2 & 10 & 0.00072 \\
\hline Balam & Palaquium sp. R. Br. & 7.9 & 2 & 10 & 0.00069 \\
\hline Kayu arang & Diospyros pilosanthera Blanco & 7.6 & 2 & 10 & 0.00065 \\
\hline Gaharu & Aquilaria malaccensis Oken & 7.5 & 2 & 10 & 0.00062 \\
\hline Kelat jambu & Eugenia densiflora Blume & 7.5 & 2 & 10 & 0.00062 \\
\hline Kayu terap & Artocarpus elastic Willd. & 7.4 & 2 & 10 & 0.0006 \\
\hline Medang & Litsea sp. Lam. & 7.3 & 2 & 10 & 0.00059 \\
\hline Medang kuning & Pimelodendron sp. Hassk. & 7.3 & 2 & 10 & 0.00059 \\
\hline Mahang gajah & Macaranga gigantean Reichb. & 7.1 & 2 & 10 & 0.00056 \\
\hline Merpayang & $\begin{array}{l}\text { Scaphium macropodum (Miq.) } \\
\text { Beumee ex Heine }\end{array}$ & 7 & 2 & 10 & 0.00055 \\
\hline Pasak bumi & Eurycoma longifolia Jack & 6.5 & 2 & 10 & 0.00047 \\
\hline Duku & Lansium domesticum Corr. & 6.2 & 1 & 5 & 0.00043 \\
\hline Cempedak & Artocarpus champeden Lour. & 6.1 & 1 & 5 & 0.00041 \\
\hline Durian & Durio zibethinus Murr. & 6 & 1 & 5 & 0.00039 \\
\hline Sungkai & Peronema canescens Jack & 5.7 & 2 & 10 & 0.00037 \\
\hline Kedondong & Spondias cyntherea Forst & 5.6 & 1 & 5 & 0.00034 \\
\hline Kabau & Archidendron bubalinum Jack & 5.6 & 1 & 5 & 0.00034 \\
\hline Kempas & Koompassia malaccensis Maing. & 5.3 & 1 & 5 & 0.00031 \\
\hline Siluk & Gironniera subaequalis Planch. & 5.2 & 1 & 5 & 0.0003 \\
\hline Medang serai & Cinnamomum parthenoxylon Jack & 5.2 & 1 & 5 & 0.0003 \\
\hline Kayu tahi & Celtis wightii Planch. & 5.1 & 1 & 5 & 0.00029 \\
\hline Berangan & Quercus elmeri Merr. & 5.1 & 1 & 5 & 0.00029 \\
\hline Simpur rawang & Dillenia indica $\mathrm{L}$. & 5.1 & 1 & 5 & 0.00029 \\
\hline Jengkol & Pithecellobium lobatum Benth & 5 & 1 & 5 & 0.00028 \\
\hline Petaling & Ochanostachys amentacea Mast. & 4.9 & 1 & 5 & 0.00026 \\
\hline Medang api & Adinandra dumosa Jack & 4.9 & 1 & 5 & 0.00026 \\
\hline Kepayang & Pangium edule Reinw. & 4.9 & 1 & 5 & 0.00026 \\
\hline Meranti bunga & Shorea teysmanniana $\mathrm{Bl}$. & 4.8 & 1 & 5 & 0.00025 \\
\hline Medang kelor & Litsea teysmanni Miq. & 4.8 & 1 & 5 & 0.00025 \\
\hline Sekentut & Saprosma arboreum Blume & 4.7 & 1 & 5 & 0.00024 \\
\hline Merawan & Hopea mengarawan Miq. & 4.7 & 1 & 5 & 0.00024 \\
\hline Ambacang & Mangifera foetida Lour. & 4.7 & 1 & 5 & 0.00024 \\
\hline Keruing & Dipterocarpus hasseltii Blume & 4.6 & 1 & 5 & 0.00023 \\
\hline Kelat & Eugenia sp. Verdc. & 4.6 & 1 & 5 & 0.00023 \\
\hline Kemang & Mangifera kemanga Blume & 4.6 & 1 & 5 & 0.00023 \\
\hline Mangga & Mangifera indica $\mathrm{L}$. & 4.6 & 1 & 5 & 0.00023 \\
\hline Tempinis & Sloetia elongate Kds. & 4.5 & 1 & 5 & 0.00022 \\
\hline Berangan babi & Castanopsis inermis Lindl. & 4.5 & 1 & 5 & 0.00022 \\
\hline Bulian & Eusideroxylon zwageri $\mathrm{T}$. et B. & 4.5 & 1 & 5 & 0.00022 \\
\hline Tempunek & Artocarpus rigida Blume & 4.1 & 1 & 5 & 0.00019 \\
\hline Karet & Hevea brasiliensis Muell. Arg. & 4.1 & 1 & 5 & 0.00018 \\
\hline Brumbung & Adina minutiflora Val. & 4.1 & 1 & 5 & 0.00018 \\
\hline Petai & Parkia speciosa Hassk. & 3.9 & 1 & 5 & 0.00017 \\
\hline Rambutan & Nephelium lappaceum $\mathrm{L}$. & 3.8 & 1 & 5 & 0.00016 \\
\hline Tampui & Baccaurea crassifolia J. J. Sm. & 3.8 & 1 & 5 & 0.00016 \\
\hline Total & & 300 & 69 & 345 & \\
\hline
\end{tabular}

rambutan (Nephelium lappaceum). The population of jernang rattan (D. draco) was only 82 individuals, smaller than other rattan such as rotan lilin (Calamus javanensis) 197 individuals, rotan semambu (C. scipionum) 178 individuals, sego air als (C. axillaris) 103 individual, rotan getah (D. melanochaetes) 102 individuals, rotan dahan (C. 
flagellaris) 95 individuals, and rotan manau $(C$. manan) 93 individuals.

To protect the forest from the increasing forest encroachment, serious efforts from the government are needed, such as increasing forest rangers that are brave and firm in enforcing the law to the encroachers. Further research is needed to estimate the population of jernang rattan in other district, because the population in Batanghari District is critical.

\section{ACKNOWLEDGEMENTS}

We are grateful to Yana Soemarna, Erwin Nurdin, Wisnu Wardana, Dr. Kuswata Kartawinata, Mega Atria, Dr. Himmah Rustiami, Titi Kalima, Totok Waluyo, Dr. Bambang Irawan, who spent time with us for discussion. The financial support and permission to conduct reseacrh by the government of Jambi are greatly appreciated.

\section{REFERENCES}

Beccari O. 1911. Asiatic palm lepidocariae the species of Daemonorops. Ann Royal Bot Gard Calcuta 12 (1): 1-237.

Bernatzky A. 1978. Tree ecology and preservation. Elsevier, San Francisco.

BKSDA Jambi. 2010. Non-timber forest products of Jambi Province. Department of Forestry, Jambi. [Indonesia]

BPS [Badan Pusat Statistik]. 2010. Jambi in Figures. Badan Pusat Statistik, Jambi. [Indonesia]

Dali Y, Soemarna Y. 1985. Cultivation of potential rattan. Prosiding Lokakarya Nasional Rotan. IDRC Canada-Badan Litbang Kehutanan, Dephut, Jakarta. [Indonesia]

Dransfield J, Manokaran N. 1994. Rattan plant resources of South-East Asia. LIPI, Jakarta.

Dransfield J. 1984. The genus Areca in Borneo. Kew Bull 39:1-22.

Dransfield J. 1992. The list of rattan in the world. Allen Press, Kansas.

Fachrul MD. 2007. Sampling methods of Bio-Ecology. Bumi Aksara, Jakarta. [Indonesia]

Harata K, Mogea JP, Rahayu M. 2005. Diversity conservation and local knowledge of rattans and sugar palm in Gunung Halimun Salak National Park Indonesia. Palms 40 (1): 25-35.

Heyne K. 1987. De Nuttige Planten van Indonesie. Badan Litbang Departemen Kehutanan, Jakarta. [Indonesia]

INTAG. 1989. Pedoman inventarisasi rotan. Direktorat Inventarisasi Hutan Departemen Kehutanan. Jakarta. [Indonesia]

Irawan B. 2002. Ironwood (Eusideroxylon zwageri) present condition and future development in Jambi, Indonesia. J Ecol 91: 222-233.

Irawan B. 2003. A study on tree diversity in association with variability of ironwood (Eusideroxylon zwageri) in Jambi, Indonesia. J Ecol 92: 10-18.

Jambi Forest Office. 2009. Annual Report. Jambi Forest Office, Jambi. [Indonesia]

Januminro CFM. 2000. Rattan of Indonesia. Pusat Penelitian Hasil Hutan, Bogor. [Indonesia]

Jasni, Damayanti R, Kalima T. 2007. Atlas of Indonesian Rattan. Pusat Penelitian dan Pengembangan Hasil Hutan, Bogor. [Indonesia]

Kalima T. 1991. Some species of Daemonorops; jernang producer and its problems. Sylva Tropika 6 (1): 15-18. [Indonesia]

Mogea JP. 1991. Utilization and conservation of Indonesian palms. In: Johnson DVJ (ed) Palms for Human Needs in Asia. A.A. Balkema, Rotterdam.

Mogea JP. 2002. Rattan in Gunung Halimun National Park and the prospects for cultivation in the village Cisungsang, Lebak, Banten. Prosiding Biodiversitas Taman Nasional Halimun 6 (1): 33-55. [Indonesia]
Table 10. Importance value index (IVI), number of individuals (n), density (n/ ha), and dominance index (DI) of trees with stem diameter $\leq$ $10 \mathrm{~cm}$.

\begin{tabular}{|c|c|c|c|c|c|}
\hline S & Scientific names & \multicolumn{2}{|c|}{ IVI n } & \multicolumn{2}{|c|}{ n/ha DI } \\
\hline & Pithecolobium saman Jacq. & 20 & 4 & 20 & 0.00018 \\
\hline & Areca catechu $\mathrm{L}$. & 20 & 4 & 20 & 018 \\
\hline kai & Peronema canescens Jack & 16 & 3 & 15 & 0.00010 \\
\hline $\mathrm{m}$ & Palaquium sp. R. Br. & 16 & 3 & 15 & 0.00010 \\
\hline lang & Macaranga hypoleuca Rechb. & 15 & 3 & 15 & 0.00010 \\
\hline igan & Castanopsis inermis Lindl. & 15 & 3 & 15 & 0.00010 \\
\hline & Litsea sp. Lam. & 12 & 3 & 15 & 0010 \\
\hline lbung & Adina minutiflora Val. & 11 & 2 & 10 & 0.00004 \\
\hline nji & Dialium platysepalum Backer & 10 & 2 & 10 & 0.00004 \\
\hline itut & Saprosma arboreum Blume & 10 & 2 & 10 & 0.00004 \\
\hline lang kuning & Pimelodendron sp. Hassk. & 10 & 2 & 10 & 0.00004 \\
\hline ng serai & parthenoxylo & 10 & 2 & 10 & 0.00004 \\
\hline nis & Sloetia elongate Kds. & 10 & 2 & 10 & 0004 \\
\hline terap & Artocarpus elastic Willd. & 10 & 2 & 10 & 0004 \\
\hline abutan & Nephelium lappaceum L. & 10 & 2 & 10 & 0.00004 \\
\hline u arang & Diospyros pilosanthera $\mathrm{Bl}$ & 9.9 & 2 & 10 & 004 \\
\hline nak & Tetrameris & 8.9 & 2 & 10 & 004 \\
\hline pur ray & Dillenia indica L. & 8.2 & 2 & 10 & 004 \\
\hline u tahi & Celtis wight & 5.3 & 1 & 5 & 001 \\
\hline taling & Ochanostachys amentacec & 5.3 & 1 & 5 & 0.00001 \\
\hline elat & Eugenia sp. Verdc. & 5.3 & 1 & 5 & 001 \\
\hline ng & Mangifera ken & 5.3 & 1 & $J$ & 001 \\
\hline aret & Hevea brasilie & 5.3 & 1 & 5 & 001 \\
\hline lat jambu & Eugenia densiflora Blume & 5.3 & 1 & 5 & 0.00001 \\
\hline oau & Archidendron bulbalium Jack & 5.3 & 1 & 5 & 0.00001 \\
\hline mpunek & Artocarpus & 5.3 & 1 & 5 & 0.00001 \\
\hline ampui & assifolia J. J. Sm. & 5.3 & 1 & 5 & 0.00001 \\
\hline empedak & Artocarpus champeden Lour. & 5.3 & 1 & 5 & 0.00001 \\
\hline acang-kacang & Strombosia javanica Blume & 5 & 1 & 5 & 0.00001 \\
\hline dlian & Eusideroxylon & 5 & 1 & 5 & 0.00001 \\
\hline lerpayang & $\begin{array}{l}\text { Scaphium macropodum (Miq.) } \\
\text { Beumee ex Heine }\end{array}$ & 5 & 1 & 5 & 0.00001 \\
\hline and & Litsea teysn & 4.7 & 1 & $J$ & 0.00001 \\
\hline Aon & Mangifera indica $\mathrm{L}$. & 4.7 & 1 & 5 & 0.00001 \\
\hline Total & & 300 & 00 & 300 & \\
\hline
\end{tabular}

Peluso NL. 1992. The ironwood problems management and development of an extractive rainforest product. Conserv Biol 6 (2): 210-219.

Purwanto Y, Polosakan R, Susiarti S, Waluyo EB. 2009. Extraction of jernang sap (Daemonorops spp.) and the possible extension. In: Purwanto Y, Walujo EB, Wahyudi A. (eds.). 2009. Valuasi hasil hutan bukan kayu setelah pembalakan (Kawasan konservasi PT Wirakarya Sakti Jambi). LIPI, Bogor: 183-198. [Indonesia]

Rugayah, Widjaya EA, Praptiwi. 2004. Guidelines for collecting data on the diversity of flora. Pusat Penelitian Biologi-LIPI, Bogor. [Indonesia]

Rustiami H, Setyowati FM, Kartawinata K. 2004. Taxonomy and uses of Daemonorops draco (Willd.). J Trop Ethnobiol 1 (2): 65-75.

Rustiami H. 2004. A new species of Daemonorops section Piptospatha (Arecaceae) from Siberut island, West Sumatra. Kew bulletin. 57 (3): $729-733$.

Simon H. 2007. Methods on forest inventory. Pustaka Pelajar, Yogyakarta. [Indonesia]

Siswanto BE. 1991. Methods of forest inventory in forest group of Sungai Aya Hulu, KPH Hulu Sungai, South Kalimantan. Buletin Penelitian Hutan 538: 13-22. [Indonesia]

Soemarna Y. 2009. Cultivation of jernang rattan (Daemonorops draco Willd). J Litbang Kehutanan 2 (3): 5-10. [Indonesia]

Winarni I, Waluyo T, Hastoeti P. 2004. An overview of jernang as potential commodity. Prosiding hasil-hasil hutan. Bogor: 173-176. [Indonesia] 